\title{
Nitrogen and Sulphur Fertilisation for Marketable Yields of Cabbage (Brassica oleracea L. var. Capitata), Leaf Nitrate and Glucosinolates and Nitrogen Losses Studied in a Field Experiment in Central Slovenia
}

\author{
Nina Kacjan Maršić ${ }^{1, *(D)}$, Ksenija Sinkovič Može ${ }^{1}$, Rok Mihelič ${ }^{1, *}$, Marijan Nečemer ${ }^{2}$, Metka Hudina ${ }^{1}(\mathbb{D}$ \\ and Jerneja Jakopič ${ }^{1}(\mathbb{D}$ \\ 1 Biotechnical Faculty, University of Ljubljana, SI-1000 Ljubljana, Slovenia; s.ksenija@gmail.com (K.S.M.); \\ metka.hudina@bf.uni-lj.si (M.H.); jerneja.jakopic@bf.uni-lj.si (J.J.) \\ 2 Jožef Stefan Institute, Jamova 39, SI-1000 Ljubljana, Slovenia; marijan.necemer@ijs.si \\ * Correspondence: nina.kacjan.marsic@bf.uni-lj.si (N.K.M.); rok.mihelic@bf.uni-lj.si (R.M.)
}

Citation: Kacjan Maršić, N.; Može, K.S.; Mihelič, R.; Nečemer, M.; Hudina, M.; Jakopič, J. Nitrogen and Sulphur Fertilisation for Marketable Yields of Cabbage (Brassica oleracea L. var. Capitata), Leaf Nitrate and Glucosinolates and Nitrogen Losses Studied in a Field Experiment in Central Slovenia. Plants 2021, 10, 1304. https://doi.org/10.3390/

plants10071304

Academic Editor: Martin Kulhanek

Received: 31 May 2021

Accepted: 25 June 2021

Published: 27 June 2021

Publisher's Note: MDPI stays neutral with regard to jurisdictional claims in published maps and institutional affiliations.

Copyright: (c) 2021 by the authors. Licensee MDPI, Basel, Switzerland. This article is an open access article distributed under the terms and conditions of the Creative Commons Attribution (CC BY) license (https:/ / creativecommons.org/licenses/by/ $4.0 /)$.
Abstract: A field trial of white cabbage (Brassica oleracea var. Capitata L.) was carried out under the humid temperate climate conditions in Central Slovenia to investigate the effects of calcium ammonium nitrate $\left(0,180\right.$ and $\left.240 \mathrm{~kg} \mathrm{~N} \mathrm{ha}^{-1}\right)$ and gypsum ( 0 and $\left.40 \mathrm{~kg} \mathrm{~S} \mathrm{ha}^{-1}\right)$ fertilisation on yield, yield quality (nitrate, glucosinolate levels and glucosinolate profile) and nitrogen use efficiency. The highest marketable yield, dry matter yield and nitrogen uptake were obtained at the highest nitrogen fertilisation rate when in combination with sulphur. For this treatment, the nitrogen surplus in the soil after harvesting was lower than for the same nitrogen fertilisation without sulphur application. For the combination $\mathrm{N}_{240} \mathrm{~S}_{40}$, the sulphur addition significantly increased nitrogen use efficiency, which resulted in reduced nitrate content in the cabbage heads. The chemical forms of glucosinolates showed that $80-85 \%$ were aliphatic glucosinolates with the remainder as the indole group. For the aliphatic glucosinolates, significant interactions between nitrogen and sulphur fertilisations were reflected in increased levels of progoitrin and glucoiberin when sulphur was applied at the lower nitrogen fertilisation rates. For the indole group, the levels of glucobrassicin and the indole group itself decreased at higher nitrogen fertilisation rates, independent of sulphur fertilisation.

Keywords: cabbage cultivation; nitrogen and sulphur fertilisation; nitrate content; glucosinolates profile; nitrogen surplus

\section{Introduction}

As an economically important members of the Brassicaceae family, white cabbage (Brassica oleracea var. Capitata L.) is consumed worldwide and is considered a good source of bioactive phytochemicals [1]. The most striking feature of such Brassica crops is their high levels of glucosinolates [2], which have chemoprotective and anticancer effects after myrosinase hydrolysis [3]. These properties of glucosinolate metabolites have motivated recent efforts to better understand the factors that influence their production in plants [4-7].

The classification of glucosinolates depends on the amino acid precursor in the side chain, and these molecules contain at least two sulphur atoms, which is the main reason for the high sulphur demand of Brassica crops [8]. Glucosinolates are known to be related to plant defence mechanisms, as they are induced after injury by herbivores or pathogens, and changes in various environmental factors, such as temperature, radiation and salt and nutrient content [1,9-11]. In addition to these the environmental effects, fertilisation with nitrogen and/or sulphur has been shown to have significant effects on the glucosinolate levels in plant tissues $[9,10]$.

The application of nitrogen fertilisers is essential for the formation of primary and secondary metabolites in plants, and together with carbon and sulphur, nitrogen is an 
important source of protein synthesis, growth and phytochemical biosynthesis. As there is also nitrogen in glucosinolates, it can be assumed that their levels increase when plant growth is limited by carbon availability, with the excess nitrogen being channelled into these secondary metabolites [12].

Over the last three decades, increasing sulphur deficiency in soils has been reported for many European countries. This is mainly due to the reduction in sulphur dioxide emissions from industrial sources, the increasing use of low sulphur fertilisers and the increase in crop yields due to the fact of technological advances [13]. Thus, sulphur has become one of the most limited nutrients in agricultural production, especially for Brassica crops. In particular, in higher plants, inorganic sulphur is assimilated into cysteine, which is subsequently converted into methionine [14]. The activities of the enzymes involved in these reduction steps are regulated by the nitrogen content in the plant $[15,16]$.

To satisfy the increasing health and environmental awareness of consumers, the demand for vegetables with high levels of health-promoting phytochemicals produced by sustainable production systems need to be fulfilled [17]. However, it is often very difficult to satisfy environmental sustainability in vegetable production, as cultivation systems are highly vulnerable to nitrogen loss (e.g., nitrate leaching, denitrification). This is largely due to the conditions of high nitrogen input, frequent cultivation, relatively short periods of plant growth and low nutrient use efficiency [18]. Various efforts to reduce fertilisation rates without compromising yield have been evaluated in white cabbage, based on improved nitrogen and water management practices [19-22], development of various breeding programmes that focus on nitrogen-efficient genotypes [23] and improved models to predict the timing of nitrogen uptake [24].

The effects on the nutritional quality of Brassicaceae plants through nitrogen and/or sulphur supplies and nutrient uptake, as well as their efficient use, have previously been studied separately $[11,20,21,25,26]$. Thus, there are few data available on the combined effects of fertilisation and nutrient use efficiency (NUE) on health-promoting compounds and the nutritional value of plants in a sustainable environment [11,26]. Furthermore, the relationships between glucosinolates in plants and nutrient availability, especially $\mathrm{N}$ and S, have been studied mainly on oilseed Brassica crops [27-32] or broccoli, turnip and mustard [11,33-35], while for cabbage such data are very scarce in the literature [9].

The objective of this study was to investigate the effects of nitrogen and sulphur fertilisation on cabbage yield and quality (as nitrate content and glucosinolate levels), nitrogen uptake and NUE and the potential for nitrogen loss on sandy loam soils under the humid temperate climatic conditions of Central Slovenia. A field trial was thus conducted to evaluate the fertilisation regime that provides high qualitative and economic yields and low potential for nitrogen loss (i.e., low postharvest soil mineral nitrogen surplus).

\section{Results}

\subsection{White Cabbage Yield and Nitrogen Uptake}

For the non-fertilised control, the marketable yield of these cabbages was $30.3 \pm 1.6 \mathrm{t} \mathrm{ha}^{-1}$. Fertilisation with $180 \mathrm{~kg} \mathrm{~N} \mathrm{ha}^{-1}$ and $40 \mathrm{~kg} \mathrm{~S} \mathrm{ha}^{-1}\left(\mathrm{~N}_{180} \mathrm{~S}_{40}\right)$ more than doubled this yield to $67.4 \pm 2.3 \mathrm{t} \mathrm{ha}^{-1}$. The yield was then further increased by increasing the nitrogen fertilisation from 180 to $240 \mathrm{~kg} \mathrm{ha}^{-1}$ to $75.82 .6 \mathrm{t} \mathrm{ha}^{-1}$, although only when sulphur was also applied with the nitrogen $\left(\mathrm{N}_{240} \mathrm{~S}_{40}\right)$ (Table 1$)$. The mean head weight of the cabbages was also higher with this treatment $\left(\mathrm{N}_{240} \mathrm{~S}_{40}\right)$ than without sulphur addition $\left(\mathrm{N}_{240} \mathrm{~S}_{0}\right)$.

No significant effects of nitrogen and/or sulphur application was observed on the proportion of marketable yield, which ranged from $70 \%$ to $78 \%$ (Table 1). Dry matter yield was higher in treatments with high nitrogen accompanied by sulphur $\left(\mathrm{N}_{240} \mathrm{~S}_{40}\right.$; $\left.8050 \pm 871 \mathrm{~kg} \mathrm{ha}^{-1}\right)$, compared to high nitrogen fertilisation without sulphur $\left(\mathrm{N}_{240} \mathrm{~S}_{0}\right.$; $7113 \pm 274 \mathrm{~kg} \mathrm{ha}^{-1}$ ) (Table 2). 
Table 1. Effects of nitrogen and sulphur fertilisation on the marketable yield parameters of white cabbage and the nitrogen and sulphur interactions.

\begin{tabular}{|c|c|c|c|c|}
\hline \multicolumn{2}{|c|}{ Fertilisation $\left(\mathrm{kg} \mathrm{ha}^{-1}\right)$} & \multirow{2}{*}{$\begin{array}{c}\text { Mean Head } \\
\text { Weight (g) }\end{array}$} & \multicolumn{2}{|c|}{ Marketable Yield } \\
\hline Nitrogen & Sulphur & & $\left(\mathrm{t} \mathrm{ha}^{-1}\right)$ & $(\%)$ \\
\hline 0 & 0 & $860 \pm 50^{c}$ & $30.3 \pm 1.6^{c}$ & $70.3 \pm 1.3$ \\
\hline 180 & $\begin{array}{c}0 \\
40\end{array}$ & $\begin{array}{l}1790 \pm 55^{b} \\
1920 \pm 60^{b}\end{array}$ & $\begin{array}{l}62.7 \pm 1.8^{b} \\
67.4 \pm 2.3^{b}\end{array}$ & $\begin{array}{l}76.2 \pm 0.8 \\
75.1 \pm 0.9\end{array}$ \\
\hline 240 & $\begin{array}{c}0 \\
40\end{array}$ & $\begin{array}{l}1900 \pm 70^{b} \\
2160 \pm 75^{a}\end{array}$ & $\begin{array}{l}66.8 \pm 2.4^{b} \\
75.8 \pm 2.6^{a}\end{array}$ & $\begin{array}{l}76.1 \pm 0.6 \\
78.1 \pm 0.7\end{array}$ \\
\hline $\mathrm{Ni}$ & & $\begin{array}{l}* * \\
\text { ns } \\
* *\end{array}$ & ns & $\begin{array}{l}\text { ns } \\
\text { ns } \\
\text { ns }\end{array}$ \\
\hline
\end{tabular}

Data are means \pm standard error $(n=4)$. Different superscript letters indicate significant differences between fertilisation treatments $\left(p<0.01\right.$; Duncan's test). ${ }^{* *} p<0.01$; ns, not significant (ANOVA), for interactions with and between nitrogen and sulphur fertilisations.

Table 2. Effects of nitrogen and sulphur fertilisation on dry matter yield and nitrogen measures for cabbage heads and wrapped leaves and the nitrogen and sulphur interactions.

\begin{tabular}{|c|c|c|c|c|c|c|c|c|}
\hline \multicolumn{2}{|c|}{$\begin{array}{l}\text { Treatments } \\
\left(\text { kg ha }^{-1}\right)\end{array}$} & \multicolumn{2}{|c|}{$\begin{array}{l}\text { Dry Matter Yield } \\
\left(\mathrm{kg} \mathrm{ha}^{-1}\right)\end{array}$} & \multicolumn{2}{|c|}{$\begin{array}{l}\text { Nitrogen Uptake } \\
\left(\mathrm{kg} \mathrm{ha}^{-1}\right)\end{array}$} & \multicolumn{3}{|c|}{$\begin{array}{c}\text { Apparent Nitrogen Recovery } \\
(\%)\end{array}$} \\
\hline Nitrogen & Sulphur & Heads & $\begin{array}{l}\text { Wrapped } \\
\text { Leaves }\end{array}$ & Heads & $\begin{array}{l}\text { Wrapped } \\
\text { Leaves }\end{array}$ & Heads & $\begin{array}{l}\text { Wrapped } \\
\text { Leaves }\end{array}$ & Together \\
\hline 0 & 0 & $3402 \pm 167^{c}$ & $2500 \pm 95^{c}$ & $52 \pm 4^{d}$ & $63 \pm 3^{c}$ & & & \\
\hline \multirow[t]{2}{*}{180} & 0 & $6750 \pm 205^{b}$ & $3140 \pm 174^{b}$ & $169 \pm 7^{c}$ & $110 \pm 4^{b}$ & 65 & 26 & 91 \\
\hline & 40 & $7133 \pm 262^{b}$ & $3465 \pm 110^{\mathrm{a}}$ & $181 \pm 8^{b c}$ & $128 \pm 8^{a}$ & 72 & 36 & 108 \\
\hline \multirow[t]{2}{*}{240} & 0 & $7113 \pm 274^{b}$ & $3274 \pm 130^{\mathrm{ab}}$ & $192 \pm 7^{b}$ & $130 \pm 5^{a}$ & 58 & 28 & 86 \\
\hline & 40 & $8050 \pm 271^{a}$ & $3330 \pm 128^{a b}$ & $225 \pm 7^{\mathrm{a}}$ & $129 \pm 6^{a}$ & 72 & 28 & 100 \\
\hline \multicolumn{9}{|c|}{ Significance } \\
\hline \multicolumn{2}{|c|}{ Nitrogen } & $* * *$ & $* * *$ & $* *$ & $* *$ & & & \\
\hline \multicolumn{2}{|c|}{ Sulphur } & ns & ns & * & * & & & \\
\hline \multicolumn{2}{|c|}{ Nitrogen $\times$ Sulphur } & $* *$ & $* *$ & ** & $* *$ & & & \\
\hline
\end{tabular}

Data are the means \pm standard error $(n=4)$. Different superscript letters indicate significant differences between fertilisation treatments $\left(p<0.01\right.$; Duncan's test). ${ }^{*} p<0.05 ;{ }^{* *} p<0.01 ;{ }^{* * *} p<0.001$; ns, not significant (ANOVA), for interactions with and between nitrogen and sulphur fertilisation. Nitrogen uptake was highest in plants fertilised with $\mathrm{N}_{240} \mathrm{~S}_{40}\left(225 \pm 7 \mathrm{~kg} \mathrm{~N}^{-1}\right)$, whereas it was significantly lower in plants grown with the same nitrogen but without sulphur $\left(\mathrm{N}_{240} \mathrm{~S}_{0} ; 192 \pm 7 \mathrm{~kg} \mathrm{~N} \mathrm{ha}^{-1}\right)$ (Table 2). There were no effects of sulphur fertilisation on nitrogen uptake in plants fertilised at the standard nitrogen rate of $180 \mathrm{~kg} \mathrm{~N} \mathrm{ha}^{-1}$.

\subsection{Nitrogen, Sulphur and Nitrate Contents in the Tissue of Cabbage Heads}

Total nitrogen content in the cabbage head tissue and in the wrapped leaves was only affected by nitrogen application, without any significant effects of addition of sulphur (Table 3). The nitrogen content increased in the heads of the control treatment from $15.2 \pm 0.6 \mathrm{~g} \cdot \mathrm{kg}^{-1}$ dry matter to $27.8 \pm 0.4 \mathrm{~g} \cdot \mathrm{kg}^{-1}$ dry matter in the heads fertilised with high nitrogen $\left(\mathrm{N}_{240} \mathrm{~S}_{40}\right.$ and $\left.\mathrm{N}_{240} \mathrm{~S}_{0}\right)$. For the wrapped leaves, the nitrogen contents with the $\mathrm{N}_{240} \mathrm{~S}_{40}$ treatment were $40 \%$ higher and $65 \%$ higher with the control plants compared to the cabbage heads under the corresponding treatments.

The sulphur content was significantly higher in cabbage heads when sulphur was applied with the nitrogen fertilisation, which resulted in a $13 \%$ increase in sulphur content for the low nitrogen $\left(\mathrm{N}_{180} \mathrm{~S}_{40}\right)$ and a $30 \%$ increase for the high nitrogen $\left(\mathrm{N}_{240} \mathrm{~S}_{40}\right)$ (Table 3). Nitrogen fertilisation also significantly increased sulphur content in the head tissue, although only when it was supplied together with sulphur. This was reflected in a $9 \%$ increase in the cabbage head sulphur content when nitrogen was increased from 180 to $240 \mathrm{~kg} \mathrm{~N} \mathrm{ha}^{-1}$. 
Table 3. The effects of nitrogen and sulphur fertilisation on tissue nitrogen and sulphur contents and the nitrogen:sulphur ratio in the tissue for cabbage heads and wrapped leaves.

\begin{tabular}{|c|c|c|c|c|c|c|c|}
\hline \multicolumn{2}{|c|}{$\begin{array}{l}\text { Treatments } \\
\left(\mathrm{kg} \mathrm{ha}^{-1}\right)\end{array}$} & \multicolumn{2}{|c|}{$\begin{array}{c}\text { Tissue Nitrogen } \\
\text { (g kg }{ }^{-1} \text { Dry Matter) }\end{array}$} & \multicolumn{2}{|c|}{$\begin{array}{c}\text { Tissue Sulphur } \\
\text { (g kg-1 Dry Matter) }\end{array}$} & \multicolumn{2}{|c|}{ Nitrogen:Sulphur Ratio } \\
\hline Nitrogen & Sulphur & Heads & $\begin{array}{l}\text { Wrapped } \\
\text { Leaves }\end{array}$ & Heads & $\begin{array}{l}\text { Wrapped } \\
\text { Leaves }\end{array}$ & Heads & $\begin{array}{l}\text { Wrapped } \\
\text { Leaves }\end{array}$ \\
\hline 0 & 0 & $15.2 \pm 0.6^{c}$ & $25.1 \pm 1.1^{\mathrm{c}}$ & $2.9 \pm 0.1^{\mathrm{d}}$ & $3.7 \pm 0.4^{\mathrm{c}}$ & $5.2 \pm 0.4^{c}$ & $7.4 \pm 1.1^{a}$ \\
\hline 180 & $\begin{array}{c}0 \\
40\end{array}$ & $\begin{array}{l}25.1 \pm 0.6^{b} \\
25.3 \pm 0.7^{b}\end{array}$ & $\begin{array}{c}35.5 \pm 1.2^{\mathrm{b}} \\
36.7 \pm 1.3^{\mathrm{ab}}\end{array}$ & $\begin{array}{l}3.8 \pm 0.2^{c} \\
4.3 \pm 0.1^{b}\end{array}$ & $\begin{array}{l}6.5 \pm 0.8^{b} \\
9.1 \pm 0.3^{a}\end{array}$ & $\begin{array}{l}6.5 \pm 0.3^{b} \\
5.9 \pm 0.1^{b c}\end{array}$ & $\begin{array}{l}6.0 \pm 1.0^{\mathrm{ab}} \\
4.4 \pm 0.3^{\mathrm{bc}}\end{array}$ \\
\hline 240 & $\begin{array}{c}0 \\
40\end{array}$ & $\begin{array}{l}27.1 \pm 0.8^{\mathrm{a}} \\
27.8 \pm 0.4^{\mathrm{a}}\end{array}$ & $\begin{array}{c}40.0 \pm 1.1^{\mathrm{a}} \\
38.9 \pm 1.3^{\mathrm{ab}}\end{array}$ & $\begin{array}{l}3.6 \pm 0.1^{\mathrm{c}} \\
4.7 \pm 0.1^{\mathrm{a}}\end{array}$ & $\begin{array}{c}6.4 \pm 0.3^{b} \\
10.8 \pm 1.3^{a}\end{array}$ & $\begin{array}{l}7.6 \pm 0.3^{a} \\
5.9 \pm 0.2^{b c}\end{array}$ & $\begin{array}{l}6.0 \pm 0.6^{\mathrm{ab}} \\
3.4 \pm 0.5^{\mathrm{c}}\end{array}$ \\
\hline \multicolumn{8}{|c|}{ Significance } \\
\hline \multicolumn{2}{|c|}{ Nitrogen } & $\begin{array}{l}* * * \\
\text { ns }\end{array}$ & $\begin{array}{l}* * * \\
* *\end{array}$ & $\begin{array}{l}* * \\
* * *\end{array}$ & $\begin{array}{l}* * \\
* *\end{array}$ & $\begin{array}{l}* * \\
* *\end{array}$ & $\begin{array}{l}* \\
*\end{array}$ \\
\hline \multicolumn{2}{|c|}{ Nitrogen $\times$ Sulphur } & $*$ & $* *$ & $* *$ & * & $* *$ & $* *$ \\
\hline
\end{tabular}

Data are the means \pm standard error $(n=4)$. Different superscript letters indicate significant differences between fertilisation treatments $\left(p<0.01\right.$; Duncan's test). ${ }^{*} p<0.05 ;{ }^{* *} p<0.01 ;{ }^{* * *} p<0.001 ; \mathrm{ns}$, not significant (ANOVA), for interactions with and between nitrogen and sulphur fertilisation.

Nitrate content in heads and wrapped leaves was also affected by nitrogen and sulphur fertilisation (Table 4). The highest nitrate content was in the heads and wrapped leaves for the high nitrogen without sulphur $\left(\mathrm{N}_{240} \mathrm{~S}_{0} ; 1816 \pm 282,3127 \pm 395 \mathrm{mg} \mathrm{NO}_{3}^{-} \mathrm{kg}^{-1} \mathrm{FW}\right.$, respectively). The addition of sulphur at this high nitrogen significantly reduced the nitrate content in both of these cabbage parts, with a nitrate reduction in the head tissue by $25 \%$, and in the wrapped leaves by $28 \%$.

Table 4. Effects of nitrogen and sulphur fertilisation on nitrate contents for cabbage heads and wrapped leaves, and the nitrogen and sulphur interactions.

\begin{tabular}{|c|c|c|c|}
\hline \multirow{2}{*}{\multicolumn{2}{|c|}{$\begin{array}{c}\text { Treatments } \\
\left(\mathrm{kg} \mathrm{ha}^{-1}\right)\end{array}$}} & \multicolumn{2}{|c|}{ Nitrate (mg kg ${ }^{-1}$ Fresh Weight) } \\
\hline & & Heads & Wrapped Leaves \\
\hline Nitrogen & \multicolumn{3}{|l|}{ Sulphur } \\
\hline 0 & 0 & $141.9 \pm 24.1^{c}$ & $114.6 \pm 84.8^{c}$ \\
\hline \multirow[t]{2}{*}{180} & 0 & $1352.1 \pm 41.8^{b}$ & $1487.8 \pm 275.1^{\mathrm{b}}$ \\
\hline & 40 & $996.2 \pm 88.2^{b}$ & $1613.3 \pm 220.0^{b}$ \\
\hline \multirow[t]{2}{*}{240} & 0 & $1816.6 \pm 281.5^{a}$ & $3127.1 \pm 394.5^{\mathrm{a}}$ \\
\hline & 40 & $1361.8 \pm 184.8^{b}$ & $2250.4 \pm 324.4^{\mathrm{b}}$ \\
\hline \multicolumn{4}{|c|}{ Significance } \\
\hline \multicolumn{2}{|c|}{ Nitrogen } & $* * *$ & $* * *$ \\
\hline \multicolumn{2}{|c|}{ Sulphur } & * & * \\
\hline \multicolumn{2}{|c|}{ Nitrogen $\times$ Sulphur } & $* *$ & $* *$ \\
\hline
\end{tabular}

Data are the means \pm standard error $(n=4)$. Different superscript letters indicate significant differences between fertilisation treatments $\left(p<0.01\right.$; Duncan's test). ${ }^{*} p<0.05 ;{ }^{* *} p<0.01 ;{ }^{* * *} p<0.001$; ns, not significant (ANOVA), for interactions with and between nitrogen and sulphur fertilisation.

\subsection{Balance of Nitrogen Input and Output}

The calculated nitrogen budget for these fertilised plots indicated that the nitrogen input exceeded the nitrogen uptake by the plants, which resulted in excess nitrogen in the soil (Table 5). The extent of the nitrogen surplus varied according to the fertilisation. The treatments with high nitrogen application without sulphur $\left(\mathrm{N}_{240} \mathrm{~S}_{0}\right)$ showed the highest nitrogen surplus (almost $53 \mathrm{~kg} \mathrm{~N} \mathrm{ha}^{-1}$ ), while the plots where high nitrogen application was accompanied by sulphur $\left(\mathrm{N}_{240} \mathrm{~S}_{40}\right)$ showed reduced nitrogen surplus $\left(19 \mathrm{~kg} \mathrm{~N} \mathrm{ha}^{-1}\right)$. The addition of sulphur to the standard nitrogen application rate also resulted in a reduction in the nitrogen surplus, from $15.0\left(\mathrm{~N}_{180} \mathrm{~S}_{0}\right)$ to only $2.2 \mathrm{~kg} \mathrm{~N} \mathrm{ha}^{-1}\left(\mathrm{~N}_{180} \mathrm{~S}_{40}\right)$. 
Table 5. Nitrogen balance: inputs and outputs.

\begin{tabular}{|c|c|c|c|c|c|}
\hline \multicolumn{2}{|c|}{$\begin{array}{l}\text { Treatments } \\
\left.\text { (kg ha }^{-1}\right)\end{array}$} & \multirow[t]{2}{*}{$\begin{array}{c}\text { Input } \\
\left(\mathrm{kg} \mathrm{N} \mathrm{ha}^{-1}\right)\end{array}$} & \multirow[t]{2}{*}{$\begin{array}{c}\text { Output (Nitrogen Uptake by } \\
\text { Crop-Cabbage Heads) } \\
\left(\mathrm{kg} \mathrm{N} \mathrm{ha}^{-1}\right)\end{array}$} & \multirow[t]{2}{*}{$\begin{array}{l}\text { Nitrogen Surplus } \\
\text { (Input-Output) } \\
(\mathbf{k g ~ N ~ h a - 1 )}\end{array}$} & \multirow[t]{2}{*}{$\begin{array}{l}\text { Nitrogen Use } \\
\text { Efficiency } \\
(\%)\end{array}$} \\
\hline Nitrogen & Sulphur & & & & \\
\hline 0 & 0 & 4.7 & 51 & - & - \\
\hline \multirow[t]{2}{*}{180} & 0 & 184.7 & 169 & 15.0 & 91.0 \\
\hline & 40 & 184.7 & 181 & 2.2 & 98.0 \\
\hline \multirow[t]{2}{*}{240} & 0 & 244.7 & 192 & 52.7 & 78.0 \\
\hline & 40 & 244.7 & 225 & 19.0 & 92.0 \\
\hline
\end{tabular}

Data are the means $(n=4)$.

\subsection{Glucosinolates Levels in Cabbage Heads}

Nine individual glucosinolates were quantitatively determined for the cabbage heads: the aliphatic glucosinolates sinigrin, gluconapin, glucoiberin, progoitrin and glucoibervirin; the indole glucosinolates 4-hydroxyglucobrassicin, glucobrassicin and neoglucobrassicin; the aromatic glucosinolate gluconasturtiin (Table 6). Total glucosinolates was calculated as the sum of these individual glucosinolates.

Although no significant differences were seen for the total glucosinolates, the standard nitrogen rate with sulphur showed the highest levels $\left(\mathrm{N}_{180} \mathrm{~S}_{40} ; 30.0 \pm 3.1 \mu \mathrm{mol} \mathrm{g}{ }^{-1} \mathrm{DW}\right)$, with similarly low levels seen across a number of the treatments $\left(\mathrm{N}_{180} \mathrm{~S}_{0} ; \mathrm{N}_{240} \mathrm{~S}_{0} ; \mathrm{N}_{240} \mathrm{~S}_{40}\right.$; $\sim 24 \mu \mathrm{mol} \mathrm{g}^{-1} \mathrm{DW}$ ) (Table 6). Significant effects of nitrogen and sulphur were seen in the levels of two of the individual aliphatic glucosinolates (i.e., glucoiberin and progoitrin) and in one of the indole glucosinolates (i.e., glucobrassicin). Fertilisation at standard nitrogen without sulphur and at high nitrogen irrespective of sulphur showed significant reductions in progoitrin compared to the control. The glucoiberin levels were lowest for both of the nitrogen fertilisation treatments without sulphur. The glucobrassicin levels decreased compared to the control treatment when standard nitrogen was applied without sulphur, while fertilisation with high nitrogen reduced glucobrassicin levels regardless of sulphur. Glucobrassicin levels also changed according to sulphur, but only at the standard nitrogen rate, with sulphur fertilisation increasing glucobrassicin levels by up to $44 \%$. 
Table 6. The effects of nitrogen and sulphur fertilisation on the individual glucosinolate levels determined for cabbage heads and the nitrogen and sulphur interactions.

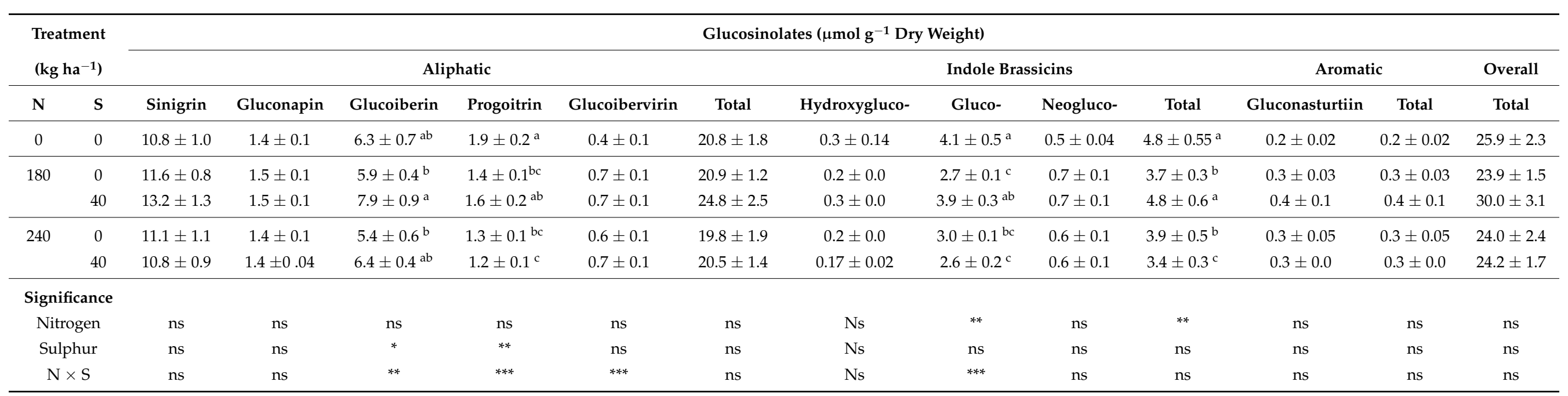

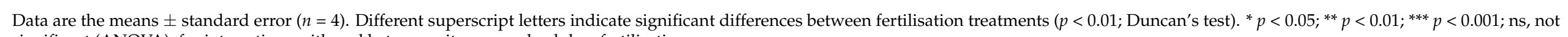
significant (ANOVA), for interactions with and between nitrogen and sulphur fertilisation. 


\section{Discussion}

\subsection{Effects of Nitrogen and Sulphur Fertilisation on Yields}

The cabbage yields in this study at least doubled with fertilisation compared to the unfertilised control. This indicates that fertilisation contributed more to cabbage yield than for other crops, where similar fertiliser application has been shown to increase yields by approximately $60 \%$, mainly for cereals and oilseeds in China and Europe [36,37]. Increasing the nitrogen from 180 to $240 \mathrm{~kg} \mathrm{~N} \mathrm{ha}^{-1}$ also resulted in increased cabbage yield, but only when sulphur was applied together with the nitrogen, which occurred in other studies with different Brassica crops [10,38,39].

As both of these nutrients are involved in the biosynthesis of proteins and many other important biomolecules, this balanced application of nitrogen and sulphur can increase their efficiency of use in crops [40]. The relationships between the roles of nitrogen and sulphur in plants can be observed in the repression of the activity of the enzyme nitrogen reductase [41], which catalyses the rate-limiting step in the nitrate assimilation pathway. This is also apparent for the regulation of ATP-sulphur lyase when nitrogen-limitation or sulphur-deficient conditions occur in plants $[40,42,43]$. Moreover, the synthesis of cysteine as a result of the incorporation of the sulphide moiety into O-acetylserine appears to be the meeting point between nitrogen and sulphur metabolism. Naturally occurring thiol compounds (e.g., cysteine, glutathione) have also been shown to affect nitrate reductase activity in Brassica plants [44].

\subsection{Effects of Nitrogen and Sulphur Fertilisation on the Nitrogen Balance in Soil and Plants}

Calculation of the nitrogen budget under the experimental conditions in the present study shows a potential risk for nitrogen loss following treatments with high nitrogen (i.e., $240 \mathrm{~kg} \mathrm{~N} \mathrm{ha}^{-1}$ ) compared to standard nitrogen (i.e., $180 \mathrm{~kg} \mathrm{~N} \mathrm{ha}^{-1}$ ) [20,21]. However, nitrogen surpluses were reduced when the gypsum sulphur was added with the nitrogen and even more so at the high nitrogen application.

However, the calculated nitrogen surpluses of all of these treatments were relatively small. Under the average meteorological conditions in such Slovenian agricultural areas, there would only be a potential threat of nitrate pollution of the ground water for a nitrogen excess of $>45 \mathrm{~kg} \mathrm{~N} \mathrm{ha}^{-1}$ [45]. Thus, even the highest nitrogen surplus in the present study of $52.7 \mathrm{~kg} \mathrm{ha}^{-1}$ at $\mathrm{N}_{240} \mathrm{~S}_{0}$ remained relatively low. The mean nitrogen surplus overall for agriculture in Slovenia has been reduced over the last 15 years, from the previous 98 to $42 \mathrm{~kg} \mathrm{~N} \mathrm{ha}^{-1}$ per year $[46,47]$. However, these data were based on all land that was used for agriculture and, thus, also poorly or non-fertilised marginal land; these data will thus not specifically represent the nitrogen surplus of the intensively cultivated land in the present study.

The NUE across all of the treatments in the present study was high, even for the lowest NUE seen for $\mathrm{N}_{240} \mathrm{~S}_{0}$, at $78 \%$. Indeed, this can be considered optimal, as proposed by the model of the panel of European experts on nitrogen fertilisation. They indicated that in common agricultural practice, NUE $>80 \%$ can lead to soil nitrogen mining and to longterm worsening of soil fertility [36]. Here, high NUE was obtained for the combination of nitrogen with gypsum (i.e., sulphur), as $98 \%$ for $\mathrm{N}_{180} \mathrm{~S}_{40}$, and $92 \%$ for $\mathrm{N}_{240} \mathrm{~S}_{40}$. Considering the data obtained here under these environmental conditions and soil types, even the high nitrogen combined with sulphur $\left(\mathrm{N}_{240} \mathrm{~S}_{40}\right)$ left only $19 \mathrm{~kg} \mathrm{~N} \mathrm{ha}^{-1}$ surplus, indicating that this economically valuable yield can be obtained without great environmental risk. This is particularly important, because most of the highly fertile arable land in Slovenia is located on plains in shallow groundwater recharge zones that are the main source of drinking water [20,48]. The relationships between the supplies of nitrogen and sulphur have been noted in many studies, as the uptake of these nutrients is strongly linked due to the fact of their central role in plants as mentioned earlier $[2,10,43]$. Therefore, a shortage of sulphur in plants is likely to result in less use of the available soil nitrogen and, thus, to an increased risk of nitrate leaching [44]. 
As well as fertilisation and other agricultural practices, the data obtained here will have been dependent also on the weather conditions, which were particularly favourable during this study, thus promoting further the high yield with good responses to fertilisation. However, for less favourable years, which include drought periods or when farmers did not fertilise with sulphur along with nitrogen, we would recommend that nitrogen fertilisation of early cabbage varieties remains closer to the standard nitrogen rate of $180 \mathrm{~kg} \mathrm{~N}^{-1}$ to reduce any adverse environmental impact. Similarly, for the same reason, it has been suggested that for late-growing cabbage varieties [49,50], the recommended fertilisation rate of $350 \mathrm{~kg} \mathrm{~N} \mathrm{ha}^{-1}$ for cabbage can be reduced without reducing the crop yield.

\subsection{Effects of Sulphur and Nitrogen Fertilisation on Nitrate Content in Cabbage}

The beneficial effects of sulphur fertilisation were reflected not only in the more efficient uptake of nitrogen in the soil but also in the more efficient nitrogen use in the plants. This was reflected in the lower nitrate content in the cabbage heads for the treatments with nitrogen combined with sulphur, compared to nitrogen without sulphur. The differences in the nitrate contents were significant in the cabbage heads fertilised with the high nitrogen rates, which thus confirmed data from other studies [11,43,51]. Indeed, sulphur application promoted the incorporation of nitrogen into organic compounds, and consequently reduced the nitrate content in the leaf. For all of these nitrogen and sulphur treatments, the nitrate content in the cabbage heads were lower than those reported for other leafy vegetables $[10,52,53]$.

\subsection{Effects of Nitrogen and Sulphur Fertilisation on Levels of Eight Glucosinolates in Cabbage Heads}

In this study, the indole glucosinolates accounted for approximately $13-19 \%$ of the total glucosinolates, while the aliphatic glucosinolates accounted for approximately $80-87 \%$. These are not consistent with previous studies with cabbage plants, in which indole glucosinolates have accounted for more like $80-85 \%[9,17,32]$. These contrasting data might be due to the different cultivars used and the different environmental conditions. Indeed, higher amounts of alkyl glucosinolates are synthesised at lower temperatures in combination with increased radiation, and high amounts of the indole glucosinolate glucobrassicin have been reported for higher temperatures $\left(>18{ }^{\circ} \mathrm{C}\right)$ and lower radiation [11]. The cabbage plants in the present study were grown from April to July, when the mean daily temperatures ranged from 12 to $19^{\circ} \mathrm{C}$, and the mean daily radiation increased a little (from 15 to $42 \mathrm{~mol} \mathrm{~m}^{-2}$ day $^{-1}$ ), which suggests that the growing conditions had major effects on the structures of the glucosinolates produced in the head tissue of these cabbage plants.

These results are important for growers and researches in most leading cabbage producing countries (South Alpine region of Europe, as well as parts of China, India, Russia and Poland) where cabbage production mainly takes place in regions with temperate, humid climatic conditions, [54-57], as they characterised the climate in this study.

The predominance of sinigrin and glucobrassicin in cabbage plants has been reported previously $[9,58]$, while the amount of the aromatic glucosinolate gluconasturtiin, which was detected in the present study, has not yet been demonstrated in cabbage plants. Considering the important anticarcinogenic activity of the degradation products of sinigrin, glucobrassicin and gluconastrurtiin $[2,59,60]$, consumption of cabbages cultivated in early summer is recommended for a healthy diet. Fertilisation with nitrogen and sulphur showed differential effects on the individual aliphatic glucosinolates and indole glucosinolates in the present study. The addition of sulphur significantly affected two of the aliphatic glucosinolates, while the addition of nitrogen resulted in significantly decreased levels of glucobrassicin and the total indole group glucosinolates. Furthermore, at the standard nitrogen fertilisation rate, the glucosinolates responses were dependent on the supply of sulphur. Effects on increasing glucosinolates levels from increasing sulphur fertilisation have been reported previously for numerous crucifers grown in low sulphur soils $[9,11,61]$, although these were only partially consistent with the present study. The lack of significant changes in sinigrin levels and the total aliphatic group in the present study might be because 
the sulphur content in the soil was high enough already to saturate the plant requirements for glucosinolates biosynthesis, which would thus mask any effects of the additional sulphur on glucosinolates synthesis. Indeed, the wet deposition of sulphur in Slovenia is the highest among European countries, at $9.8 \mathrm{~kg} \mathrm{~S} \mathrm{ha}^{-1}$ year $^{-1}$ [62]. Nevertheless, similar results for fertiliser's effect on quality parameters in cabbage plants could be expected for studies conducted in Europe countries and China, where similar pedoclimatic conditions are regulated by temperate continental climate and sufficient rainfall, both of which best suit the growth requirements of cabbage plants $[13,62,63]$.

The data for the indole glucosinolates levels here indicated that nitrogen and sulphur have important roles in the regulation of glucosinolates synthesis in cabbage heads. The indole glucosinolates levels were high when the nitrogen and sulphur were not at adequate levels (i.e., control, unfertilised plants), and these decreased with increasing nitrogen fertilisation. When the nitrogen was added at above the standard nitrogen rate $\left(\mathrm{S}_{240}\right)$, and regardless of the sulphur, the indole glucosinolates levels decreased, which is consistent with previous studies $[9,29,64]$. This might be the consequence of sulphur deficiency in the synthesis of glucosinolates in plants that was caused by the high nitrogen fertilisation. Indeed, for broccoli and oilseed rape, it has been shown that for glucosinolates synthesis, for every 10 (or even fewer) parts nitrogen, there is one part sulphur [65]. Schonhof et al. reported [11] that a higher nitrogen:sulphur ratio resulted in lower glucosinolates production in broccoli heads, which is partially consistent with the present study. Here, the increase in nitrogen fertilisation resulted in an increase in the nitrogen:sulphur ratio $\left(\mathrm{N}_{0} \mathrm{~S}_{0}, 5.2\right.$ (control plants); $\left.\mathrm{N}_{180} \mathrm{~S}_{0}, 6.5 ; \mathrm{N}_{240} \mathrm{~S}_{0}, 7.6\right)$ and a decrease in the indole levels (4.8-3.7 $\left.\mu \mathrm{mol} \mathrm{g}{ }^{-1} \mathrm{DW}\right)$.

Indole glucosinolates are derived from the sulphur-free amino acid tryptophan, and their levels do not normally change due to the fact of sulphur fertilisation, as is seen for the aliphatic glucosinolates, which are derived from the sulphur-containing amino acid methionine $[14,66]$. However, sulphur fertilisation in the present study increased the indole glucosinolates in the cabbage plants grown at the standard nitrogen fertilisation rates $\left(180 \mathrm{~kg} \mathrm{~N} \mathrm{ha}^{-1}\right)$. These data are in agreement with previously reported suggestions that an increased sulphur supply increases glucosinolates levels in Brassica plants, as these plants assimilate inorganic sulphate into cysteine, which is subsequently converted to methionine, where this reduction step is regulated by nitrogen $[5,66]$. Moreover, the synthesis of the indole glucosinolates from tryptophan is dependent on the thiohydroximate sulphur donor (i.e., cysteine or methionine) as a precursor of indole glucosinolates [14].

In further studies with cabbage plants, a cultivation site with low soil sulphur should be selected and a wider range of nitrogen and sulphur fertilisation rates should be used to obtain the clearer effects of nitrogen and sulphur fertilisation on glucosinolates accumulation in white cabbage and to determine the rate at which the yield increases to the point where fertilisation does not result in significant negative environmental effects.

\section{Conclusions}

Increased nitrogen fertiliser up to $240 \mathrm{~kg} \mathrm{~N} \mathrm{ha}^{-1}$ combined with a sulphur supply resulted in higher cabbage yields and nitrogen uptake. Among the fertiliser rates tested in this study, and under the given experimental conditions, the combination of $240 \mathrm{~kg} \mathrm{~N} \mathrm{ha}^{-1}$ with $40 \mathrm{~kg} \mathrm{~S} \mathrm{ha}^{-1}$ reduced the nitrogen surplus after harvest and was the most suitable for cabbage cultivation from both the economical (yield) and ecological (leaching potential) points of view. For the plants grown at the high nitrogen rate $\left(240 \mathrm{~kg} \mathrm{~N} \mathrm{ha}^{-1}\right)$, sulphur addition increased NUE, which was reflected in lower nitrate content in the cabbage heads. The structures of the glucosinolates in the cabbage heads showed that the predominant glucosinolates belong to the aliphatic group, where their synthesis is stimulated by lower temperatures and increased light conditions, which is consistent with the growing conditions in the present study, and which indicates an important role for the growing conditions in terms of glucosinolates synthesis. The nitrogen and sulphur fertilisation affected the levels of some of the glucosinolates. The interactions of nitrogen and sulphur fertilisation 
were significant for glucoiberin and progoitrin levels for the aliphatic glucosinolates and for the glucobrassicin levels from the indole glucosinolates. This was reflected in increased levels with the low nitrogen rate when sulphur was also applied. Nitrogen fertilisation resulted in decreased indole glucosinolates levels, probably due to the sulphur deficiency for glucosinolates synthesis as a result of the increased nitrogen fertilisation.

\section{Materials and Methods}

\subsection{The Field Experiment: Site Description, Soil Properties and Weather}

The experiment was conducted in an experimental field at Dolnje Brezovo $\left(45^{\circ} 59^{\prime} 38^{\prime \prime} \mathrm{N}\right.$, $15^{\circ} 22^{\prime} 21^{\prime \prime} \mathrm{E} ; 170 \mathrm{~m}$ a.s.1.), approximately $67 \mathrm{~km}$ east of Ljubljana, the capital of Slovenia. The field is part of 40 ha of agricultural land where intensive vegetable production has been ongoing for nearly 30 years. Soil samples for determination of texture classification and basic nutrient analysis were taken before and after the experiment, and the physical and chemical properties of the soil are given in Table 7. The soil of the experimental site was classified as gleyic fluvisol and endogleyic fluvisol, according to the World References Base for Soil Resources (2015). The laboratory analyses included soil texture, organic matter, $\mathrm{pH}$, plant-available phosphorus $\left(\mathrm{P}_{2} \mathrm{O}_{5}\right)$ and potassium $\left(\mathrm{K}_{2} \mathrm{O}\right)($ ammonium lactate method) [67]. Determination of total sulphur in soil was carried out by energy-dispersive X-ray fluorescence (EDXRF) spectrometry [68].

Table 7. Chemical and physical properties of the soil of the Dolnje Brezovo experimental area used in the present study.

\begin{tabular}{ccc}
\hline Parameter & Units & Value \\
\hline $\mathrm{pH}\left(0.01 \mathrm{M} \mathrm{CaCl}_{2}: \mathrm{H}_{2} \mathrm{O}, 1: 5\right)$ & - & 7.3 \\
Total organic carbon content & $\mathrm{mg} / \mathrm{kg}$ & 19,000 \\
Total nitrogen content & $\mathrm{mg} / \mathrm{kg}$ & 1600 \\
Phosphate (ammonium lactate method) & $\mathrm{mg} / \mathrm{kg}$ & 250 \\
Potassium (ammonium lactate method) & $\mathrm{mg} / \mathrm{kg}$ & 173 \\
Sulphur (total) (EDXRF spectrometry) & $\mathrm{mg} / \mathrm{kg}$ & 180 \\
$\mathrm{C} / \mathrm{N}$ weight ratio & - & 11.9 \\
\hline Soil fraction content & $(\%)$ & 55.3 \\
Sand & & 33.2 \\
Silt & & 11.5 \\
Clay & - & Sandy loam \\
\hline Soil texture & &
\end{tabular}

The mean annual precipitation in the study area for the 1981-2010 reference period was $1179 \mathrm{~mm}$, and the average annual air temperature was $8.9^{\circ} \mathrm{C}$ (ARSO, 2014), measured at the nearest representative meteorological station of Novo Mesto $\left(45^{\circ} 48^{\prime} 6.5^{\prime \prime} \mathrm{N}, 15^{\circ} 10^{\prime} 38.3^{\prime \prime} \mathrm{E}\right.$; $220 \mathrm{~m}$ a.s.l.). Data for precipitation and air temperatures for the growing season are shown in Figure 1. During the growing period, the mean daily temperature was above the 30 year average by $1.6{ }^{\circ} \mathrm{C}$ in April and by $0.8-1.6{ }^{\circ} \mathrm{C}$ in May, June and July. Precipitation exceeded the 30 year average in total by $28 \mathrm{~mm}$, with the greatest excess in April $(28 \mathrm{~mm}$ above the average). In May and July, precipitation was $5 \mathrm{~mm}$ and $14 \mathrm{~mm}$ above the average, respectively, while in June it was $20 \mathrm{~mm}$ below the average.

\subsection{Design and Management of the Field Experiment}

The experiment was laid out in a randomised complete block design with four replications. Each block (replicate) consisted of five plots (fertilisation treatments). Each plot was $1.9 \times 3 \mathrm{~m}^{2}$, with 20 plants per plot. The distance between rows was $0.75 \mathrm{~m}$, and between plants within rows, $0.38 \mathrm{~m}$. Cabbage (Brassica oleracea var. Capitata L.) cv. 'Nozomi F1' (Sakata, Japan) transplants were purchased from the Dutch Transplant Organisation, and 35 day old transplants were transplanted into the field on 15 April 2014. 


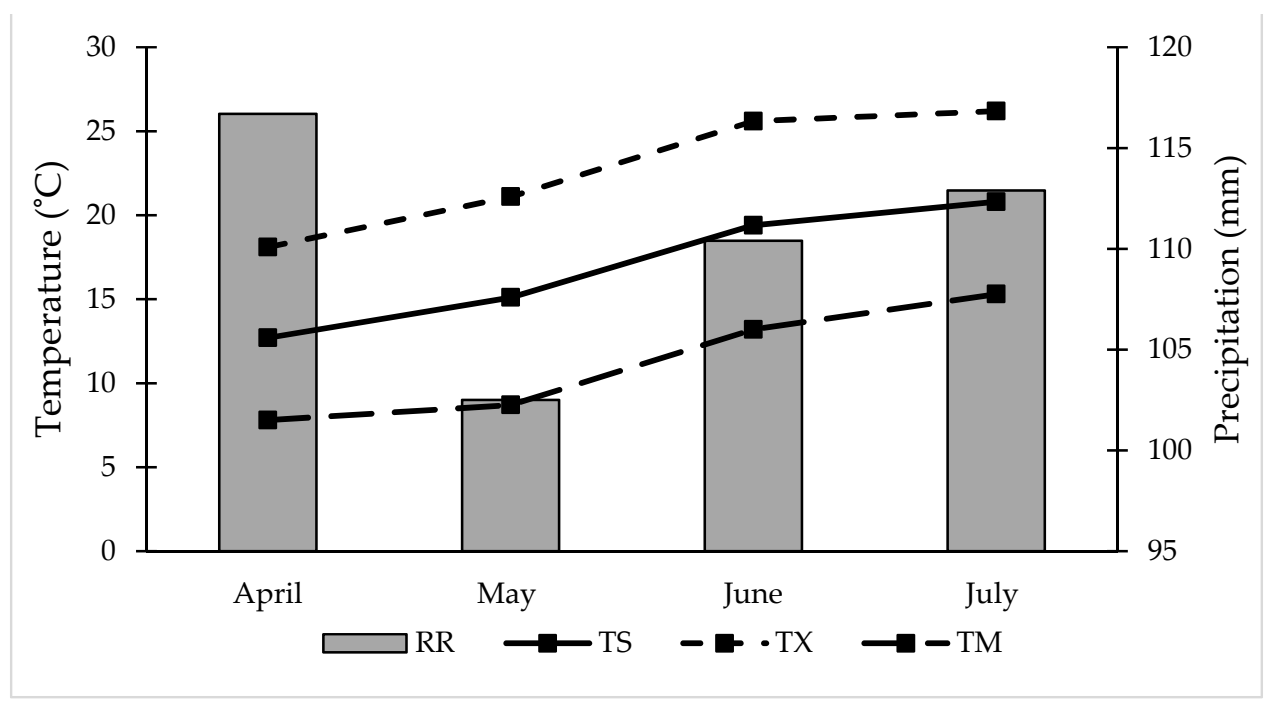

Figure 1. Monthly meteorological data from April to July 2014 for the Novo Mesto meteorological station. Data were obtained from the Environmental Agency of the Republic of Slovenia (ARSO, 2014). TS, mean monthly air temperature; TX, mean daily maximum temperature; TM, mean daily minimum temperature; RR, precipitation.

The five fertiliser treatments used were the unfertilised control plot $\left(\mathrm{N}_{0} \mathrm{~S}_{0}\right) ; 180 \mathrm{~kg} \mathrm{~N} \mathrm{ha}^{-1}$ without $\left(\mathrm{N}_{180} \mathrm{~S}_{0}\right)$ and with $40 \mathrm{~kg} \mathrm{~S} \mathrm{ha}^{-1}\left(\mathrm{~N}_{180} \mathrm{~S}_{40}\right) ; 240 \mathrm{~kg} \mathrm{~N}$ ha $^{-1}$ without $\left(\mathrm{N}_{240} \mathrm{~S}_{0}\right)$ and with $40 \mathrm{~kg} \mathrm{~S}^{-1}\left(\mathrm{~N}_{240} \mathrm{~S}_{40}\right)$. Calcium ammonium nitrate (27\% nitrogen) was used as the nitrogen source, and the gypsum product 'Calcin S' (20\% calcium, 16\% sulphur; Cinkarna Celje, Slovenia) was used as the source of sulphur. Phosphorus (as superphosphate, $14 \%$ $\mathrm{P}_{2} \mathrm{O}_{5}$ ) was added at the equivalent of $80 \mathrm{~kg} \mathrm{P}_{2} \mathrm{O}_{5} \mathrm{ha}^{-1}$, potassium (as $\mathrm{KCl}, 60 \% \mathrm{~K}_{2} \mathrm{O}$ ) at the equivalent of $300 \mathrm{~kg} \mathrm{~K}_{2} \mathrm{O} \mathrm{ha}^{-1}$. The nitrogen, phosphorus, potassium and sulphur fertilisers were manually distributed over the soil surface 1 day before transplanting. These amounts of the added fertilisers were based on the recommendations for the integrated production of vegetables [69].

The irrigation was managed according to local agricultural practices, i.e., $20 \mathrm{~mm}$ of water using tank sprinklers on the day before and the day after transplanting (DAT). During the experimental period, the irrigation regime was generally adjusted to the actual weather conditions in the field to avoid water stress.

\subsection{Sampling and Sample Preparation}

Cabbage heads were harvested $68 \mathrm{DAT}$, at the maturity stage as defined by the density of heads (i.e., heads were compact and hard when the top of the head is pinched by a finger, and the wrapped leaves that were tight against the heads curled up a little). Samples (six plants per repetition) were randomly taken from the centre of the experimental plot. The weight of each cabbage head with wrapped leaves and without wrapped leaves (i.e., marketable weight) was measured, and the total yield was calculated using the fresh head weight, with multiplication by the number of plants per square metre. The yield was expressed in tons per hectare, and $20 \%$ of the total yield was removed to account for the tractor wheel paths, where plants would not have been planted under normal field production conditions.

\subsection{Nitrogen, Sulphur and Dry Matter Content of Plants}

Total nitrogen and dry matter content of the plants were determined by harvesting six plants at maturity from each repetition of each treatment. The plants were divided into the subsamples of the edible part (i.e., heads) and non-edible part (i.e., wrapped leaves). The cabbage fractions were cut and mixed. Subsamples of about $500 \mathrm{~g}$ were dried at $60{ }^{\circ} \mathrm{C}$ for determination of dry matter content and subsequently analysed for total nitrogen, 
which was determined after incineration at $900{ }^{\circ} \mathrm{C}$ using a thermal conductivity detector (Elementar VarioMAX CN analyser; Germany) (ISO 13878). The measurement uncertainty was $9 \%$.

The nitrate content in the fresh samples were determined in water extracts using a UV/Vis spectrometer (Lambda 2; Perkin-Elmer) with a flow injection analysis system (Neumann and Bassler, 1976). The measurement uncertainty was $17 \%$.

Dry matter yield $\left(\mathrm{kg} \mathrm{ha}^{-1}\right)$ and nitrogen uptake $\left(\mathrm{kg} \mathrm{N} \mathrm{ha}^{-1}\right)$ were calculated according to Equations (1) and (2), respectively.

$$
\begin{aligned}
& \text { Drymatteryield }\left(\mathrm{kgha}^{-1}\right)=\mathrm{FW}(\mathrm{kg}) \times \frac{10000}{\text { Areaharvested }\left(\mathrm{m}^{2}\right)} \times \frac{\mathrm{SDW}}{\mathrm{SFW}} \\
& \mathrm{N}_{\text {uptake }}\left(\mathrm{kg} \mathrm{ha}^{-1}\right)=\text { Drymatteryield }\left(\mathrm{kgha}^{-1}\right) \times \frac{\% \mathrm{~N} \text { in plant tissue }}{100}
\end{aligned}
$$

where FW $(\mathrm{kg})$ is the fresh weight of the sample per area harvested, and SDW $(\mathrm{kg})$ and SFW $(\mathrm{kg})$ are the dry and fresh weights of the subsamples, respectively. The harvested area is in $\mathrm{m}^{2}$, and the value of 10,000 has the units of $\mathrm{m}^{2} \mathrm{ha}^{-1}$. Total nitrogen uptake $\left(\mathrm{kg} \mathrm{ha}^{-1}\right)$ was calculated by multiplying the dry matter yield of the plant parts (i.e., head and wrapped leaves) by the corresponding nitrogen content in the plant parts.

Determination of total sulphur was carried out by non-destructive energy-dispersive X-ray fluorescence (EDXRF) spectrometry. The pellets were prepared with $0.5-1.0 \mathrm{~g}$ of the powdered samples using a pellet die and a hydraulic press. For excitation, a disc radioisotope excitation source of $55 \mathrm{Fe}$ was used $(25 \mathrm{mCi}$; Eckert \& Ziegler). The emitted fluorescent radiation was measured using EDXRF with a detector (XR-100SDD; Amptek), a digital pulse processor (PX5; Amptek) and a PC-based multichannel analyser software package (DPPMCA; Amptek). The spectrometer was equipped with a vacuum chamber. The energy resolution of the spectrometer was $125 \mathrm{eV}$ at $5.9 \mathrm{keV}$. The complex X-ray spectra were analysed using the AXIL Spectral Analysis Programme [68,70]. This required the statistical uncertainties of the measured intensities and the uncertainties of the mathematical fitting procedure. For these purposes, quantification was performed using the Quantitative Analysis of Environmental Samples software that was developed in our laboratory $[68,70]$. The estimated uncertainties in the analysis were between $5 \%$ and $10 \%$. The relatively high total estimated uncertainty was mainly due to the matrix correction and the geometry of the calibration procedures that included errors in the tabulated fundamental parameters. It might also have arisen from the effects of the spectrum acquisition and analysis. The accuracy of the data was checked using the National Institute of Standards and Technology reference materials: 1547 (peach leaves) and 1573a (tomato leaves).

\subsection{Apparent N Recovery and Nitrogen Use Efficiency}

The cumulative apparent nitrogen recovery (ANR) was calculated as the difference between the cumulative $\mathrm{N}$ removed (CNR) by the crop in each treatment less the control treatment, divided by the total cumulative $\mathrm{N}$ added (CNA) for the treatment, expressed as a percentage. This parameter provides an estimate of the efficiency of the applied fertiliser.

The NUE was defined in this study as the degree that the nitrogen input contributes to the nitrogen contained in the products. This was calculated as the total nitrogen contained in the products, divided by the total nitrogen input, including the fertiliser, as in Equation (3) [37]:

$$
\text { NUE }(\%)=\frac{\text { Harvested } \mathrm{N}}{\text { Total } \mathrm{N} \text { input to cropland }}
$$

\subsection{Glucosinolate Analysis in the Plants}

Extraction and desulphonisation of the glucosinolates was carried out according to the standardised method (International Standards Organisation, 1992). Briefly, the freezedried plant material was ground to a fine powder in liquid nitrogen. The powder $(0.2 \mathrm{~g})$ was heated to $70{ }^{\circ} \mathrm{C}$ for $3 \mathrm{~min}$ to inactivate endogenous myrosinase to thus prevent the 
degradation of the glucosinolates. This was added to $2 \mathrm{~mL}$ boiled $70 \% \mathrm{MeOH}$, and left for $10 \mathrm{~min}$ at $70{ }^{\circ} \mathrm{C}$. The sample was then centrifuged at $10,000 \times \mathrm{g}$ for $5 \mathrm{~min}$ (5810 R centrifuge; Eppendorf, Hamburg, Germany). The supernatant was collected in a centrifuge tube, and the sample was re-extracted with $2 \mathrm{~mL}$ of $70 \%$ boiled $\mathrm{MeOH}$. After centrifugation, the second supernatant was added to the first in the centrifuge tube, and pure water was added to $5 \mathrm{~mL}$. The supernatant was applied to a DEAE Sephadex A- 25 column $(500 \mathrm{~mL})$, which was washed twice with $1 \mathrm{~mL}$ sodium acetate buffer (0.02 M at pH 4.0). Desulphation was carried out by the addition to the column of $75 \mu \mathrm{L}$ diluted purified sulphatase solution, with the columns left overnight at ambient temperature. The columns were then eluted twice with $750 \mu \mathrm{L}$ pure water, and the eluate was collected in a vial.

The individual glucosinolates were identified and quantified using high-performance liquid chromatography (Accela HPLC system; Thermo Scientific, San Jose, CA, USA) according to ISO 9167-1:1992 (International Standards Organisation, 1992). This system included a photodiode array detector and was controlled through the chromatography workstation software (CromQuest 4.0). The column (Gemini C18; $150 \mathrm{~mm} \times 4.6 \mathrm{~mm} 3 \mu \mathrm{m}$; Phenomenex, Torrance, CA, USA) was operated at $30^{\circ} \mathrm{C}$. Mobile phases A $(100 \%$ water $)$ and $\mathrm{B}(20 \%$ acetonitrile in water; $v / v)$ were applied from $100 \% \mathrm{~A}$ at $0 \mathrm{~min}$ to $100 \% \mathrm{~B}$ at $20 \mathrm{~min}$ and then isocratic for $5 \mathrm{~min}$, before returning to the initial conditions. The flow rate was $1 \mathrm{~mL} \mathrm{~min}{ }^{-1}$, the injection volume was $20 \mu \mathrm{L}$ and the wavelength for determination was $229 \mathrm{~nm}$.

The eluent from the HPLC was interfaced with a triple-quadrupole mass spectrometer (TSQ Quantum Access MAX; Thermo Scientific, San Jose, CA, USA) via a heated electrospray ionisation probe operated in positive ion mode at an operating temperature of $350{ }^{\circ} \mathrm{C}$ and a vaporiser temperature of $50^{\circ} \mathrm{C}$. High-purity nitrogen was used as the sheath (60 units) and auxiliary (15 units) gas. Positive ion tandem mass spectrometry was used to detect desulphoglucosinolates with selected reaction monitoring. The scan event cycle used a full scan mass spectrum with a range of $\mathrm{m} / \mathrm{z}$ 200-650 and the corresponding data-dependent tandem mass spectrometry events.

The levels of the individual desulphoglucosinonates were calculated according to the response factors, and the levels are expressed as $\mu \mathrm{mol}$ equivalents of desulphosinigrin $\mathrm{g}^{-1}$ dry weight (DW).

\subsection{Statistical Analysis}

Two-way analysis of variance (ANOVA) was used for the effects of the nitrogen and sulphur fertilisation and their interactions on the parameters tested (i.e., cabbage yield, dry matter yield, nitrogen and sulphur contents in the plants, nitrogen uptake by the plants and nitrogen and nitrate distribution between the marketable parts of the plants and wrapped leaves), using the Statgraphics Centurion programme (Manugistics Inc., Rockville, MD, USA). Differences between treatments were estimated using Duncan's multiple comparison tests at a significance level of $p=0.05$.

Author Contributions: Conceptualisation, N.K.M., R.M., J.J. and K.S.M.; methodology, N.K.M. and K.S.M.; software, N.K.M.; validation, K.S.M. and J.J.; formal analysis, K.S.M., R.M., M.N., investigation, N.K.M., M.N., J.J. and R.M.; resources, M.H.; data curation, N.K.M.; writing-original draft preparation, N.K.M.; writing-review and editing, R.M. and J.J.; visualisation, J.J.; supervision, M.N. and R.M.; project administration, M.H. All authors have read and agreed to the published version of the manuscript.

Funding: The authors acknowledge the core research funds (Nos. P4-0013 'Horticulture', P4-0085 'Agroecosystems' and P6-0282 'Objects and Prestige: Taste, Status, and Power (Researches of the Material Culture in Slovenia')) that were financially supported by the Slovenian Research Agency.

Institutional Review Board Statement: Not applicable.

Informed Consent Statement: Not applicable. 
Data Availability Statement: All data pertaining to this study is being held in computers owned by the University of Ljubljana, Ljubljana, Slovenia, under the control of the IP team.

Acknowledgments: Authors are thankful to Christopher Berrie for revising the English text.

Conflicts of Interest: The authors declare no conflict of interest.

\section{References}

1. Jahangir, M.; Abdel-Farid, I.B.; Kim, H.K.; Choi, Y.H.; Verpoorte, R. Healthy and unhealthy plants: The effect of stress on the metabolism of Brassicaceae. Environ. Exp. Bot. 2009, 67, 23-33. [CrossRef]

2. Zhou, C.; Zhu, Y.; Luo, Y. Effects of Sulfur Fertilization on the Accumulation of Health-Promoting Phytochemicals in Radish Sprouts. J. Agric.Food Chem. 2013, 61, 7552-7559. [CrossRef] [PubMed]

3. Faulkner, K.; Mithen, R.; Williamson, G. Selective increase of the potential anticarcinogen 4-methylsulphinylbutyl glucosinolate in broccoli. Carcinogenesis 1998, 19, 605-609. [CrossRef] [PubMed]

4. Hayes, J.D.; Kelleher, M.O.; Eggleston, I.M. The cancer chemopreventive actions of phytochemicals derived from glucosinolates. Eur. J. Nutr. 2008, 47, 73-88. [CrossRef] [PubMed]

5. Verkerk, R.; Schreiner, M.; Krumbein, A.; Ciska, E.; Holst, B.; Rowland, I.; De Schrijver, R.; Hansen, M.; Gerhäuser, C.; Mithen, R. Glucosinolates in Brassica vegetables: The influence of the food supply chain on intake, bioavailability and human health. Mol. Nutr. Food Res. 2009, 53, S219. [CrossRef]

6. Jakopic, J.; Weber, N.; Cunja, V.; Veberic, R.; Slatnar, A. Brussels Sprout Decapitation Yields Larger Sprouts of Superior Quality. J. Agric. Food Chem. 2016, 64, 7459-7465. [CrossRef] [PubMed]

7. Zaghdoud, C.; Carvajal, M.; Moreno, D.A.; Ferchichi, A.; Martinez-Ballesta, M.D. Health-promoting compounds of broccoli (Brassica oleracea L. var. Italica) plants as affected by nitrogen fertilisation in projected future climatic change environments. J. Sci. Food Agric. 2016, 96, 392-403. [CrossRef]

8. Falk, K.L.; Tokuhisa, J.G.; Gershenzon, J. The effect of sulfur nutrition on plant glucosinolate content: Physiology and molecular mechanisms. Plant Biol. 2007, 9, 573-581. [CrossRef]

9. Rosen, C.J.; Fritz, V.A.; Gardner, G.M.; Hecht, S.S.; Carmella, S.G.; Kenney, P.M. Cabbage yield and glucosinolate concentrations as affected by nitrogen and sulfur fertility. Hortscience 2005, 40, 1493-1498. [CrossRef]

10. De Pascale, S.; Maggio, A.; Pernice, R.; Fogliano, V.; Barbieri, G. Sulphur fertilization may improve the nutritional value of Brassica rapa L. subsp Sylvestris. Eur. J. Agron. 2007, 26, 418-424. [CrossRef]

11. Schonhof, I.; Blankenburg, D.; Mueller, S.; Krumbein, A. Sulfur and nitrogen supply influence growth, product appearance, and glucosinolate concentration of broccoli. J. Plant Nutr. Soil Sci. 2007, 170, 65-72. [CrossRef]

12. Scheible, W.-R.; Morcuende, R.; Czechowski, T.; Fritz, C.; Osuna, D.; Palacios-Rojas, N.; Schindelasch, D.; Thimm, O.; Udvardi, M.K.; Stitt, M. Genome-wide reprogramming of primary and secondary metabolism, protein synthesis, cellular growth processes, and the regulatory infrastructure of Arabidopsis in response to nitrogen. Plant Physiol. 2004, 136, 2483-2499. [CrossRef]

13. Zhao, F.; McGrath, S.; Blake-Kalff, M.; Link, A.; Tucker, M. Crop responses to sulphur fertilisation in Europe. Nawozy $i$ Nawożenie $2003,5,3$.

14. Nikiforova, V.; Freitag, J.; Kempa, S.; Adamik, M.; Hesse, H.; Hoefgen, R. Transcriptome analysis of sulfur depletion in Arabidopsis thaliana: Interlacing of biosynthetic pathways provides response specificity. Plant J. 2003, 33, 633-650. [CrossRef]

15. Koprivova, A.; Suter, M.; Op den Camp, R.; Brunold, C.; Kopriva, S. Regulation of sulfate assimilation by nitrogen in Arabidopsis. Plant Physiol. 2000, 122, 737-746. [CrossRef] [PubMed]

16. Kopriva, S. Regulation of sulfate assimilation in Arabidopsis and beyond. Ann. Bot. 2006, 97, 479-495. [CrossRef]

17. Zhao, X.; Rajashekar, C.; Carey, E.E.; Wang, W. Does organic production enhance phytochemical content of fruit and vegetables? Current knowledge and prospects for research. HortTechnology 2006, 16, 449-456. [CrossRef]

18. European Union. Commision Regulation (EC) No 1525/98 of maximum levels for certain contaminants in foodstuffs. Communities 1998, 201, 43-46.

19. Šturm, M.; Kacjan-Maršić, N.; Zupanc, V.; Bračič-Železnik, B.; Lojen, S.; Pintar, M. Effect of different fertilisation and irrigation practices on yield, nitrogen uptake and fertiliser use efficiency of white cabbage (Brassica oleracea var. Capitata L.). Sci. Hortic. 2010, 125, 103-109. [CrossRef]

20. Zupanc, V.; Šturm, M.; Lojen, S.; Maršić-Kacjan, N.; Adu-Gyamfi, J.; Bračič-Železnik, B.; Urbanc, J.; Pintar, M. Nitrate leaching under vegetable field above a shallow aquifer in Slovenia. Agric. Ecosyst. Environ. 2011, 144, 167-174. [CrossRef]

21. Maršić, N.K.; Šturm, M.; Zupanc, V.; Lojen, S.; Pintar, M. Quality of white cabbage yield and potential risk of ground water nitrogen pollution, as affected by nitrogen fertilisation and irrigation practices. J. Sci. Food Agric. 2012, 92, 92-98. [CrossRef] [PubMed]

22. Urlić, B.; Dumičić, G.; Goreta Ban, S. Zinc and sulfur effects on growth and nutrient concentrations in Rocket. Commun. Soil Sci. Plan. 2014, 45, 1831-1839. [CrossRef]

23. Dewi, E.R.; Nikus, O.; Horst, W.J. Genotypic differences in nitrogen efficiency of white cabbage (Brassica oleracea L.). Plant Soil 2010, 328, 313-325.

24. Feller, C.; Fink, M. Nmin target values for field vegetables. In Workshop Towards and Ecologically Sound Fertilisation in Field Vegetable Production, Wageningen, The Netherlands, 12 February 2002; Booij, R., Neeteson, J., Eds.; ISHS: Leuven, Belgium, 2002 ; pp. $195-201$. 
25. Masclaux-Daubresse, C.; Daniel-Vedele, F.; Dechorgnat, J.; Chardon, F.; Gaufichon, L.; Suzuki, A. Nitrogen uptake, assimilation and remobilization in plants: Challenges for sustainable and productive agriculture. Ann. Bot. 2010, 105, 1141-1157. [CrossRef]

26. Stavridou, E.; Kristensen, H.L.; Krumbein, A.; Schreiner, M.; Thorup-Kristensen, K. Effect of differential N and S competition in inter- and sole cropping of Brassica species and lettuce on glucosinolate concentration. J. Agric. Food Chem. 2012, 60, 6268-6278. [CrossRef]

27. Gugała, M.; Sikorska, A.; Zarzecka, K. The effect of fertilization with sulphur, boron, and amino acids on the content of glucosinolate in winter rape seeds. Agronomy 2020, 10, 519. [CrossRef]

28. Borpatragohain, P.; Rose, T.J.; Liu, L.; Raymond, C.A.; Barkla, B.J.; King, G.J. Seed glucosinolate yield is maximized by higher rates of sulfur nutrition than required for seed yield in condiment mustard (Brassica juncea L.). PLoS ONE 2019, 14, e0213429. [CrossRef]

29. Kim, S.-J.; Matsuo, T.; Watanabe, M.; Watanabe, Y. Effect of nitrogen and sulphur application on the glucosinolate content in vegetable turnip rape (Brassica rapa L.). Soil Sci. Plant Nutr. 2002, 48, 43-49. [CrossRef]

30. Ahmad, G.; Jan, A.; Arif, M.; Jan, M.; Khattak, R. Influence of nitrogen and sulfur fertilization on quality of canola (Brassica napus L.) under rainfed conditions. J. Zhejiang Univ. Sci. B 2007, 8, 731-737. [CrossRef]

31. Fismes, J.; Vong, P.; Guckert, A.; Frossard, E. Influence of sulfur on apparent N-use efficiency, yield and quality of oilseed rape (Brassica napus L.) grown on a calcareous soil. Eur. J. Agron. 2000, 12, 127-141. [CrossRef]

32. Zhao, F.; Evans, E.J.; Bilsborrow, P.E.; Syers, J.K. Influence of sulphur and nitrogen on seed yield and quality of low glucosinolate oilseed rape (Brassica napus L). J. Sci. Food Agric. 1993, 63, 29-37. [CrossRef]

33. Vallejo, F.; Tomas-Barberan, F.A.; Benavente-Garcia, A.G.; Garcia-Viguera, C. Total and individual glucosinolate contents in inflorescences of eight broccoli cultivars grown under various climatic and fertilisation conditions. J. Sci. Food Agric. 2003, 83, 307-313. [CrossRef]

34. Zhang, H.; Schonhof, I.; Krurnbein, A.; Gutezeit, B.; Li, L.; Stuezel, H.; Schreiner, M. Water supply and growing season influence glucosinolate concentration and composition in turnip root (Brassica rapa ssp rapifera L.). J. Plant Nutr. Soil Sci. 2008, 171, 255-265. [CrossRef]

35. Jensen, C.; Mogensen, V.; Mortensen, G.; Fieldsend, J.; Milford, G.; Andersen, M.; Thage, J. Seed glucosinolate, oil and protein contents of field-grown rape (Brassica napus L.) affected by soil drying and evaporative demand. Field Crop. Res. 1996, 47, 93-105. [CrossRef]

36. Panel, E.N.E. Nitrogen Use Efficiency (NUE) an Indicator for the Utilization of Nitrogen in Food Systems; Wageningen University, Alterra: Wagening, The Netherlands; Available online: https:/ / www.wur.nl/en/Publication-details.htm?publicationId=publication-way353031383832 (accessed on 15 December 2015).

37. Zhang, X.; Davidson, E.A.; Mauzerall, D.L.; Searchinger, T.D.; Dumas, P.; Shen, Y. Managing nitrogen for sustainable development. Nature 2015, 528, 51-59. [CrossRef]

38. Rhoads, F.; Olson, S. Cabbage Response to Sulfur Source and Nitrogen Rate. In Proceedings of the Soil and Crop Science Society of Florida Proceedings, Immokalee, FL, USA, 22-27 September 2000; pp. 37-40.

39. Teuber, O.; Samarappuli, D.; Berti, M. Nitrogen and Sulfur Fertilization in Kale and Swede for Grazing. Agronomy 2020, 10, 619. [CrossRef]

40. Ahmad, A.; Abdin, M. Interactive effect of sulphur and nitrogen on the oil and protein contents and on the fatty acid profiles of oil in the seeds of rapeseed (Brassica campestris L.) and mustard (Brassica juncea (L). Czern. and Coss.). J. Agron. Crop Sci. 2000, 185, 49-54. [CrossRef]

41. Jamal, A.; Moon, Y.-S.; Zainul Abdin, M. Sulphur-a general overview and interaction with nitrogen. Aust. J. Crop Sci. 2010, 4, 523.

42. Hillwig, M.S.; Chiozza, M.; Casteel, C.L.; Lau, S.T.; Hohenstein, J.; Hernández, E.; Jander, G.; MacIntosh, G.C. Abscisic acid deficiency increases defence responses against M yzus persicae in A rabidopsis. Mol. Plant Pathol. 2016, 17, 225-235. [CrossRef]

43. Scherer, H.W. Sulphur in crop production. Eur. J. Agron. 2001, 14, 81-111. [CrossRef]

44. Lakkineni, K.; Abrol, Y. Sulphur requirement of crop plants: Physiological analysis. Fertil. News 2012, $39,11-18$.

45. Mihelič, R.; Kastelec, D.; Rupreht, J. Determination of zones in Slovenia with potential risk of soil percolate contamination with nitrate-nitrogen. Novi izzivi v poljedelstvu 2002. Zbornik simpozija, Ljubljana, Slovenia 5-6 decembra 2002, 2002, $196-200$.

46. Ronchi, S.; Salata, S.; Arcidiacono, A.; Piroli, E.; Montanarella, L. Policy instruments for soil protection among the EU member states: A comparative analysis. Land Use Policy 2019, 82, 763-780. [CrossRef]

47. Simoncini, R.; Ring, I.; Sandström, C.; Albert, C.; Kasymov, U.; Arlettaz, R. Constraints and opportunities for mainstreaming biodiversity and ecosystem services in the EU's Common Agricultural Policy: Insights from the IPBES assessment for Europe and Central Asia. Land Use Policy 2019, 88, 104099. [CrossRef]

48. Curk, M.; Glavan, M.; Pintar, M. Analysis of Nitrate Pollution Pathways on a Vulnerable agricultural plain in Slovenia: Taking the local approach to balance ecosystem services of food and water. Water 2020, 12, 707. [CrossRef]

49. Kosson, R.; Felczyński, K.; Szwejda-Grzybowska, J.; Grzegorzewska, M.; Tuccio, L.; Agati, G.; Kaniszewski, S. Nutritive value of marketable heads and outer leaves of white head cabbage cultivated at different nitrogen rates. Acta Agric. Sect. B Soil Plant Sci. 2017, 67, 524-533. [CrossRef]

50. Everaarts, A.; Booi, R. The effect of nitrogen application on nitrogen utilization by white cabbage (Brassica oleracea var. Capitata) and on nitrogen in the soil at harvest. J. Hortic. Sci. Biotech. 2000, 75, 705-712. [CrossRef] 
51. He, C.-J.; Drew, M.C.; Morgan, P.W. Induction of enzymes associated with lysigenous aerenchyma formation in roots of Zea mays during hypoxia or nitrogen starvation. Plant Physiol. 1994, 105, 861-865. [CrossRef]

52. Kacjan-Maršić, N.; Osvald, J. Nitrate content in lettuce (Lactuca sativa L.) grown on aeroponics with different quantities of nitrogen in the nutrient solution. Acta Agric. Hung. 2002, 50, 389-397. [CrossRef]

53. Santamaria, P. Nitrate in vegetables: Toxicity, content, intake and EC regulation. J. Sci. Food Agric. 2006, 86, 10-17. [CrossRef]

54. Kanwar, M.; Mir, M.S.; Akbar, P.I. Effect of protected structures on cabbage production in freezing winters of Ladakh Region. Indian J. Hortic. 2011, 1, 23-25.

55. Singh, B.; Devi, J. Improved production technology for cole crops (Brassica oleracea). Prod. Techn. Veg. Crops 2015, 59, 102-119.

56. Razin, A.; Buharov, A.; Buharova, A.; Razin, O. Economic efficiency of irrigation and mineral nutrition in white head cabbage seed production in central chernozem region. Veg. Crops Russia 2015, 55-58. [CrossRef]

57. Czyżewski, A.; Czakowski, D. Selected economic relationships on the fruit and vegetable market in Poland (1994-2013). J. Agribus. Rural Dev. 2016, 42, 511-519. [CrossRef]

58. Park, S.; Arasu, M.V.; Lee, M.-K.; Chun, J.-H.; Seo, J.M.; Lee, S.-W.; Al-Dhabi, N.A.; Kim, S.-J. Quantification of glucosinolates, anthocyanins, free amino acids, and vitamin C in inbred lines of cabbage (Brassica oleracea L.). Food Chem. 2014, 145, 77-85. [CrossRef] [PubMed]

59. Dinkova-Kostova, A.T.; Kostov, R.V. Glucosinolates and isothiocyanates in health and disease. Trends Mol. Med. 2012, 18, 337-347. [CrossRef] [PubMed]

60. Verhoeven, D.T.; Goldbohm, R.A.; van Poppel, G.; Verhagen, H.; van den Brandt, P.A. Epidemiological studies on brassica vegetables and cancer risk. Cancer Epidem. Biomar. 1996, 5, 733-748.

61. Øvsthus, I.; Breland, T.A.; Hagen, S.F.; Brandt, K.; Wold, A.-B.; Bengtsson, G.B.; Seljasen, R. Effects of organic and waste-derived fertilizers on yield, nitrogen and glucosinolate contents, and sensory quality of broccoli (Brassica oleracea L. var. Italica). J. Agric. Food Chem. 2015, 63, 10757-10767. [CrossRef]

62. Keresztesi, Á.; Birsan, M.-V.; Nita, I.-A.; Bodor, Z.; Szép, R. Assessing the neutralisation, wet deposition and source contributions of the precipitation chemistry over Europe during 2000-2017. Tellus B 2019, 31, 50. [CrossRef]

63. Fang, Y.; Wang, X.; Zhu, F.; Wu, Z.; Li, J.; Zhong, L.; Chen, D.; Yoh, M. Three-decade changes in chemical composition of precipitation in Guangzhou city, southern China: Has precipitation recovered from acidification following sulphur dioxide emission control? Tellus B 2013, 65, 20213. [CrossRef]

64. Wiesner, M.; Zrenner, R.; Krumbein, A.; Glatt, H.; Schreiner, M. Genotypic Variation of the Glucosinolate Profile in Pak Choi (Brassica rapa ssp Chinensis). J. Agric. Food Chem. 2013, 61, 1943-1953. [CrossRef]

65. Ceccotti, S. Plant nutrient sulphur-a review of nutrient balance, environmental impact and fertilizers. Fertil. Res. 1995, 43, 117-125. [CrossRef]

66. Grubb, C.D.; Abel, S. Glucosinolate metabolism and its control. Trends Plant Sci. 2006, 11, 89-100. [CrossRef]

67. Egnér, H.; Riehm, H.; Domingo, W. Untersuchungen über die chemische Bodenanalyse als Grundlage für die Beurteilung des Nährstoffzustandes der Böden II. Chemische Extraktionsmethoden zur Phosphor-und Kaliumbestimmung. K. Lantbr. Ann. 1960, $26,199-215$.

68. Necemer, M.; Kump, P.; Vogel-Mikuš, K. Use of X-ray Fluorescence-Based Analytical Techniques in Phytoremediation; Nova Science Publishers, Inc.: New York, NY, USA, 2011; pp. 331-358.

69. Eur-Lex. Opinion of the European Economic and Social Committee on 'Integrated Production in the European Union' (Own-Initiative Opinion); EUR-Lex: Brussels, Belgium, 2014.

70. Nečemer, M.; Kump, P.; Ščančar, J.; Jaćimović, R.; Simčič, J.; Pelicon, P.; Budnar, M.; Jeran, Z.; Pongrac, P.; Regvar, M. Application of X-ray fluorescence analytical techniques in phytoremediation and plant biology studies. Spectrochim. Acta B 2008, 63, 1240-1247. [CrossRef] 